STUDI

FRANCESI

\section{Studi Francesi}

Rivista quadrimestrale fondata da Franco Simone

180 (LX | III) | 2016

Varia

\title{
Serge Lusignan, L'università di Parigi e la cultura letteraria in lingua francese (XIII-XIV secolo)
}

\author{
Maria Colombo Timelli
}

\section{(2) OpenEdition}

\section{Journals}

\section{Édition électronique}

URL : http://journals.openedition.org/studifrancesi/5238

DOI : 10.4000/studifrancesi.5238

ISSN : 2427-5856

\section{Éditeur}

Rosenberg \& Sellier

\section{Édition imprimée}

Date de publication : 1 décembre 2016

Pagination : 502

ISSN : 0039-2944

\section{Référence électronique}

Maria Colombo Timelli, « Serge Lusignan, L'università di Parigi e la cultura letteraria in lingua francese (XIIXIV secolo) », Studi Francesi [En ligne], 180 (LX | III) | 2016, mis en ligne le 01 janvier 2017, consulté le 18 septembre 2020. URL : http://journals.openedition.org/studifrancesi/5238 ; DOI : https://doi.org/ 10.4000/studifrancesi.5238

Ce document a été généré automatiquement le 18 septembre 2020.

\section{(i) $\$$

Studi Francesi è distribuita con Licenza Creative Commons Attribuzione - Non commerciale - Non opere derivate 4.0 Internazionale. 


\title{
Serge Lusignan, L'università di Parigi e la cultura letteraria in lingua francese (XIII-XIV secolo)
}

\author{
Maria Colombo Timelli
}

\section{RÉFÉRENCE}

SERGE LUSIGNAN, L'università di Parigi e la cultura letteraria in lingua francese (XIII-XIV secolo), in Comunicare nel Medioevo. La conoscenza e l'uso delle lingue nei secoli XII-XV, a cura di Isa Lori Sanfilippo e Giuliano Pinto, Roma, Istituto Storico Italiano per il Medio Evo, 2015, pp. 211-223.

1 L'histoire de la langue en une perspective sociolinguistique apporte parfois des lumières importantes sur les études littéraires. Tel est le cas pour cette contribution de Serge Lusignan, spécialiste du rapport entre latin et langue vulgaire au Moyen Âge, qui reprend ici la question de la diglossie latin-français au sein de l'université de Paris entre XIII ${ }^{\mathrm{e}}$ et XIV ${ }^{\mathrm{e}}$ siècle. L'affirmation fréquente et presque banale selon laquelle le latin était à cette époque la seule langue admise dans les collèges universitaires n'est pas fausse, même si au moins un statut, celui du collège de Cluny, qui accueillait les membres de l'ordre des bénédictins, faisait état de la possibilité et même de la nécessité d'avoir recours au français pour s'exercer dans la pratique oratoire. D'autres documents témoignent, souvent indirectement, d'une situation nuancée au sein même de l'école: par exemple, les grammaires dérivées de Donat pour enseigner les rudiments du latin, bien connues depuis quelques décennies, ou la maîtrise de la langue littéraire de la part de quelques auteurs de formation universitaire (Henri d'Andeli, Jean le Teinturier, Rutebeuf); d'autre part, les étudiants destinés aux carrières ecclésiastique et juridique se devaient aussi de maîtriser parfaitement la langue vulgaire. Encore, si les prologues des traducteurs semblent affirmer d'une seule voix l'insuffisance du français vis-à-vis de la richesse de la langue classique, on ne saurait oublier l'affirmation, 
étonnante par sa modernité, de Nicole Oresme posant le parallélisme entre le latin langue des Romains et le français langue maternelle des Français. Les conclusions, «paradoxales» aux yeux de S.L. lui-même (p. 222) sont donc les suivantes: malgré ses statuts officiels, l'université de Paris représentait un milieu de contact entre les deux langues plutôt que de seule opposition, et les hommes qu'elle a formés étaient certainement à même d'exposer une pensée articulée en français; par conséquent, pour rendre compte de l'écart entre latin et français aux XIII et XIV ${ }^{e}$ siècles on ne pourra que faire appel à une explication idéologique, par laquelle le latin représentait de fait la langue identitaire de l'Église. 